\title{
RADIO : THÉORISER LE FUTUR THÉORISER AU FUTUR
}

\section{RADIO : THEORISING THE FUTURE THEORISING IN FUTURE}

\author{
Guy Starkey ${ }^{1}$
}

Predictions of radio's future have often been wrong. At its birth, few people predicted that radio would enjoy a hundred years of success, while over the last fifty years many people have incorrectly predicted its demise. It was technological innovation that gave birth to the medium, yet today as technological advance gathers pace, many are again predicting the end of radio - at least as we know it. How, though, can we be confident in prediction as an indication of radio's future, especially when prediction itself is becoming inherently less reliable?

\section{La radio : une histoire de pronostics erronés Radio : a history of erroneous predictions}

Les premières émissions furent caractérisées comme la "téléphonie sans fil", c'est-à-dire une technologie plutôt envisagée comme réservée aux forces armées.

1 Principal Lecturer, University of Sunderland, United Kingdom.

Recherches en communication, $\mathrm{n}^{\circ} 26$ (2007). 
The very first radio transmissions were the final realisation in practice of a scientific theory long suspected to be feasible. When this theory was successfully and convincingly demonstrated by Guglielmo Marconi, it consisted of a crude point-to-point message to a small audience gathered around a receiver tuned in to a prearranged frequency in anticipation of hearing that message. These messages, mere blips sent over long distances, were for the first time transmitted without the need for a direct connection to be established by wire between sender and receiver. The significance of this new technology for person-to-person communication was quickly and widely perceived, yet its potential as a means of mass communication was slow to occur to a world reliant on print for the widespread dissemination of news, information and ideas.

While a large constituency of enthusiasts for wireless communication quickly emerged, as the short-wave set began to proliferate as a device for transmitting as well as receiving messages, and even when voice transmission eclipsed Morse Code as the preferred means of communication over the airwaves, radio was still perceived as an extension of the concept of telephony, rather than a performance or exhibition medium. So important did the sending and receiving of messages become to the armed forces of various nations, that radio 'hams', or short-wave enthusiasts, were criticised for interfering with what were perceived as the more deserving military transmissions on which European armies and navies began to depend (Crisell 1994 : 17-18). It was not until the Canadian, Reginald Fessenden, devised and transmitted a radio programme almost one hundred years ago, that this new medium first demonstrated its potential for mass appeal to disparate audiences over large areas.

La prolifération des téléviseurs dans les années cinquante et soixante suggéra la mort de la radio, mais l'invention du transistor la ressuscita grâce à la portabilité des nouveaux postes.

Radio's success over the ensuing fifty years until the middle of the last century is well documented. Eclipsing the music hall as a source of nightly family entertainment and challenging the newspaper and the cinematic newsreel for the dissemination of up to date news and information, radio commanded massive audiences, particularly after dark when medium wave transmissions reached farther around the curvature of the Earth to increase choice for domestic and international audiences 
alike. While the cinema offered audiences pictures, both informative and escapist, the radio brought the world into the home, so that a single receiver in the house could educate, entertain and inform whole families without the need to go out.

However, technological advance provided radio with its first real challenge : the television. Now even pictures from afar could also enter the home, and pride of place in the living room went to the television set, rather than the radio, in every household that could afford it. Faced with this challenge, it appeared to many that radio's days were numbered. Yet, technological advance came to the medium's rescue, with the invention of the transistor set : smaller than the valve set, compact, and most importantly, highly portable (Fesneau 2004; Crisell 1994 : 28). Once again, the soothsayers were confounded, and the repositioning of many radio broadcasters as purveyors of sequence programming based on pop music allowed the medium to rediscover impressive daytime audiences, keen to hear the new music of the rock and roll revolution. In the United Kingdom this new appetite was demonstrated most dramatically by the offshore pirates, broadcasting from sea - outside territorial limits.

La BBC et le Comité Pilkington (1962) n'anticipèrent point la demande pour une radio destinée aux « jeunes » avant l'arrivée des radio-pirates de haute mer, mais après 1967 l'audience fut de 17 millions pour Radio 1 - la preuve qu'ils avaient tort.

As if determined to show how out of touch they were with the population they were intended to serve, the $\mathrm{BBC}$ and the governmental Pilkington Committee on the future of broadcasting (1962) had perceived no demand for all-day music radio. They lacked both understanding and vision in failing to predict the success of such formats and the pirates exploited the void they left in the broadcasting landscape as they went on to lead the way in showing how radio could build new audiences for new types of programming (Starkey 2007a : 29). Because the BBC and Pilkington failed to provide what the public wanted, the pirates did it first and proved them wrong : in their millions daytime audiences tuned into Radios Caroline and London and a growing number of competitors anchored around the coast. Established in 1997 to replace the pirates, BBC Radio 1's audience soon reached 17 million. 
Les radios commerciales au R-U envisagèrent de gagner la majorité de l'écoute radiophonique pendant les années quatrevingt-dix, mais elles ont perdu leur pourcentage majoritaire en 1999 et jusqu' au dernier sondage les pourcentages ont également baissé.

Once the pirates had demonstrated the size of the market for commercial radio, in a country where a state broadcaster had enjoyed a monopoly of broadcasting for forty years, a change of government heralded the arrival of legal, landbased 'independent' radio, financed by private capital and run for profit. Growing in size and in confidence, the commercial sector soon began to predict that, as the number of independent stations increased, and coverage of the country became almost complete, it would not be long before their share of listening would eclipse that of the BBC. In 1991 the Association of Independent Radio Companies (AIRC) rejoiced in the BBC's share of all listening falling to 'a new low of 56.7 per cent' (AIRC 1991). With three new national commercial stations and one hundred and forty more local ones due to begin broadcasting over the next ten years, it was widely predicted that the BBC would be overtaken in the 1990s. In fact, an exponential growth in the commercial sector at the same time as the BBC virtually stood still, did bear out these predictions at first. In the first quarter of 1997, commercial radio's share grew to 49.4 per cent, compared with the BBC's 48.4 per cent (RAJAR, 1997). Then those predictions were confounded and for a variety of reasons, even as the number of commercial stations continued to grow - and still continues today - the BBC regained the larger share in the third quarter of 1999 (RAJAR). Since then it has only consolidated its lead, driving the once confident commercial sector into a defensive corner from which it scowls and curses at the BBC's success, sniping jealously at the Corporation's comparatively generous state funding as if it were the only reason for its greater appeal (Starkey 2003 : 303-19).

La proposition de l'écoute par l'Internet paraît fortement séduisante, mais au R-U en 2006 elle n'atteint que 2,1\% de l'écoute totale.

As technological advance has continued to open up new ways of reaching audiences, the prospect of internet listening appears very seductive. As soon as traditional radio stations began to offer live 
streams of their output on the web, hundreds more emerged worldwide, mostly created expressly for distribution through the internet. Many are little more than automated streams of songs interspersed with idents, rolling continuously round the twenty-four hour clock, with as much human intervention behind them as an i-Pod on shuffle mode. With so much choice and the ready availability of potential listeners while they work or play at their PCs, predictions abound even today that internet listening will find huge, if inevitably disparate, audiences around the globe. Yet, in the second quarter of 2006, in the United Kingdom one of the most connected of nations, with a developing broadband network - those predictions have also been confounded. Listening via the internet, expressed as a share of all listening rather than reach, was a mere 2.1 per cent of the total (RAJAR 2006). This seems a surprisingly low figure, particularly given internet radio's huge potential and data to suggest that in terms of reach, as many as one in five people may access internet radio at some point in the week. However, even those who do listen to internet radio still listen to radio for far longer periods or more often through other platforms, so at the present rate of growth the most optimistic predictions for web radio will remain mere wishful thinking for some time.

Le DAB, version Eureka 147, a fait croire au futur de la radio en Europe, mais il a échoué dans plusieurs pays. Néanmoins ce fut un grand succès au R-U - dans $13+\%$ des foyers.

When another promising platform, DAB, (or Digital Audio Broadcasting,) was first launched under the Eureka 147 standard in 1995, it seemed that it would soon prove to be a popular replacement for traditional analogue radio, and that Europe would lead the world in using digital technology to improve the technical quality of reception and vastly increase choice for listeners. A controversy still rages among a range of different stakeholders - from a community radio lobby fearing exclusion through a broadening digital divide, to commentators in the trade press questioning those claims of technical superiority - particularly in the light of narrowing bandwidths being used by broadcasters seeking to commercially exploit the concessions given to them by regulators through the licensing process, and the need to invest heavily in infill transmitters in order to resolve significant gaps in coverage. However, despite an initially enthusiastic response, exploitation of the format across Europe has been very patchy. Real enthusiasm for DAB 
among governments and broadcasters alike has been very variable, and predictions of an analogue switch off in radio highly problematic. Only in the United Kingdom has DAB made significant inroads into radio listening, yet there it has confounded its critics, being adopted in over 13 per cent of households (RAJAR 2006).

Au final, quand, exactement, fut l'age d'or de la radio ? Dans les années trente, cinquante, soixante, quatre-vingt... ou de nos jours, avec un choix de services impressionnant et sans précédant?

So, as we look to the past to contemplate the track record of predictions of radio's future, we can find plenty of examples where even the best of educated guesses, however well-informed and seductive they may have seemed, have been proven wrong. Governments and an unsuspecting public alike have been repeatedly caught unawares by radio's popularity as a medium, while since the 1950s soothsayers have been predicting radio's demise without vindication. When, exactly, was radio's 'golden age' ? Was it the 1930s, when the medium's novelty and popularity may have been at their peak? The 1950s, before television became the market leader among mass communication media in the evenings? The 1960s, when new forms of radio excited younger generations of listeners keen to adopt radio as their own, a way of hearing the newest music and joining their own cultural revolution ? The 1980 s, as the free radio and community radio movements swept across Europe, enfranchising alienated communities by allowing them access to the airwaves and so, their own voice in the broadcasting landscape (Starkey 2007a :28-9) ? Or is radio's golden age the present day, despite all the uncertainties of the multi-media world, now that listeners enjoy unprecedented choice through a proliferation of services which would have seemed unimaginable in past decades when scarcity of frequency demanded rationing through tight regulation? 


\section{Comment théoriser le futur de la radio, face aux incertitudes d'aujourd'hui ? \\ How to theorise the future of radio, in the face of the uncer- tainties of today?}

La convergence des moyens de dissémination, grâce aux multiples avances technologiques, déstabilise l'intégrité des médias traditionnels.

If predicting radio's future has been problematic before now, today it is even more so. Since radio's birth, the pace of technological advance has been exponential : that is, it has quickened dramatically since the digital revolution began to open up new possibilities in production and transmission in the late 1980s and 1990s. Today we might identify increasing convergence of distribution technologies as likely to destabilise the integrity of traditional media (Starkey 2007b). Radio is now received via the television, enjoying a surprising popularity in the United Kingdom among households with Sky satellite and Freeview terrestrial digital capability. Broadband and cable connections continue to grow in number and we live in one of the best connected of territories in the world, where television and film services are readily available both live and on demand. Radio is to be found on the mobile phone networks, as are text, still images and television programming. Those who would argue that radio is the medium of choice only among those who cannot access images gleefully predict radio's demise with an amnesia for the fallibility of their predecessors that might seem amusing, if it weren't for widespread fears in our own industry that they may have a point.

La section Radio \& Music de la BBC devint Audio \& Music en 2006 - mais qu'est-ce que cela veut dire <audio> et où sont les frontières de la radio ?

The response from some broadcasters has been defensive. As if forgetful of its origins as a provider of only radio broadcasting, the BBC renamed its Radio \& Music section 'Audio \& Music' in 2006, in recognition of the various new ways in which its audio output can now be accessed. Determined not to be eclipsed by the advances in technology we have observed, the provision of accompanying material to be accessed by web users has become a sine qua non of gaining a BBC commission to produce radio or television for independent and in-house 
producers alike. With the loss of the term 'radio' may come further blurring of the distinction between that which is produced for a live transmission and that which is intended for downloading. Producing speechintensive, hour-long magazine programmes entitled One Click for transmission by the youth network BBC Radio One at 3am, yet making it available on a twenty-four hour basis as a download, suggested to many that this was a way of circumventing the tight content regulation of radio transmissions where expectations around standards of taste and decency are at their highest in daytime and the evening. Asking where all this might end might well lead pessimists to conclude that radio as we know it may have an uncertain future.

De nouvelles avances technologiques menacent de déstabiliser la télévision plus que la radio - par exemple IpTV et YouTube.

However, radio is not the only medium facing uncertainty. Many of the advances in distribution technology also threaten to destabilise television. The concept of a few large networks, each with vast receipts from advertising that can support lavish production and programme acquisition budgets, was already under threat from the many lowcost, low-quality channels of repeats, tarot readings, fatuous phone-in competitions, striptease and the like, that have proliferated worldwide through digital satellite platforms. The same internet connectivity behind internet radio now presents television with new forms of competition as well. IpTV has the potential to grow the multichannel offer much further, and the first clear evidence of audience demand for viewer generated content lies in the huge success in 2006 of YouTube. Just as listeners now access the radio through the television, the trend towards increasing technological convergence suggests watching television received via the internet may become as popular as watching it via terrestrial and satellite means.

La DAB dépassera 50\% des foyers du R-U en 2010, selon le Digital Radio Development Bureau.

Other trends we can observe today, but cannot guarantee will continue, include the growth of DAB radio in certain specific countries where the market has been stimulated by some particular iniative, such as regulator intervention, as is the case with the United Kingdom. The industry body, the Digital Radio Development Bureau (DRDB), 
forecasts that receivers will be in over 50 per cent of UK households by 2010 , and it is in this context that serious consideration of analogue switch off of radio is still entertained (DRDB 2006).

La globalisation rendra-t-elle la gestion et la régulation des radios nationales plus problématiques?

We can only guess at the extent to which increasing globalisation might make a difference. That is, management and regulation of radio within individual nation states being more problematic than they are today (Starkey, 2007c). Issues of foreign ownership include syndication and automation.

Au R-U, le groupe GCap Media, propriétaire du seul multiplexe DAB commercial, dénonça en 2005 la création d'un deuxième multiplexe commercial qui risque d'accabler l'inversion digitale de GCap.

Finally, it is worth noting that the interests of the commercial sector do not always coincide with those of the listener. We have observed that commercial radio entrepreneurs have previously stimulated the industry, their profit motive shaking state broadcasters and governments alike out of the complacency of the monopoly years. Profit usually requires prior investment, and in the United Kingdom the largest radio group, GCap Media, invested heavily at the behest of the regulator in creating what it thought would be the only national commercial multiplex, Digital One. Imagine GCap's annoyance, voiced by Chief Executive Ralph Bernard at the 2005 Radio Festival in Edinburgh, at new proposals by the new regulator, Ofcom, to licence a second such multiplex in direct competition with their own. Commercial decisions over investments are also subject to the uncertainties of prediction, and it seemed in 2005 that Digital One's business plan was about to be severely disrupted by an unforeseen turn of events.

En septembre 2006 GCap, l'Ofcom (Office of Communications) et le DCMS (Department of Culture, Media \& Sport) s'accordent sur une réduction de $70 \%$ jusqu'à $60 \%$ de la radio sur le multiplexe DAB national, en faveur de l'émission de données. GCap estime gagner 13 millions d'euros en 2006 en louant une partie du multiplexe national à BT Movio - un service de 
télévision mobile émis sur des fréquences autrement réservées au DAB.

However, in September 2006, GCap, Ofcom and the governmental Department of Culture, Media and Sport (DCMS) reached an agreement allowing Digital One to reduce the total bandwidth devoted to radio on its national multiplex from 70 per cent to 60 per cent, in order to allow it to transmit a greater proportion of unrelated but relatively much more lucrative data services, including one of television programming for mobile phone distribution, BT Movio. GCaps' initial estimates of a 13 million euro income from this initiative will certainly have sugared the pill of increased competition on DAB, despite this wholesale transfer of frequencies previously allocated to radio broadcasting from radio to television.

\section{La leçon de l'histoire pour l'avenir The lessons of history for the future}

L'habitude d'avoir tort rend les pronostics du futur moins plausibles. L'instabilité épistémologique des pronostics les rend moins utiles pour l'industrie, ainsi que pour la recherche académique. La vitesse de l'avance technologique accélère toujours, et le changement qu'elle entraîne est exponentiel. Théoriser la radio reste aussi important que toujours, mais au futur la théoriser nécessitera davantage de courte vue que de vue à long terme.

We have observed and commented upon a number of instances in the past, in which the act of predicting the future of radio has been proven quite wrong. In fact, as this account is by no means exhaustive and examines but a single European territory, it seems reasonable to suggest that a history of mispredicting the future makes future predictions less plausible. Predictions are epistemologically unstable because until the future arrives there is a lack of certainty around their reliability. This instability is as critical for the academic as it is for the investor. Furthermore, (and if we may yet attempt a prediction of our own,) as the pace of technological advance may well continue to increase exponentially, so too will the rate of change. As change can happen now much more quickly than in previous decades, thanks to advances which have already been made, over time the longevity of predictions is likely to decrease rather than increase. Theorising radio will remain as important 
as ever, but academics will have to be more short-sighted than longsighted in future.

\section{References}

AIRC (1991) Press release, London : Association of Independent Radio Companies Crisell, A (1994) Understanding Radio, London : Routledge

DRDB (2006) 'DAB digital radio in 50\% of UK households by 2010', press release, 17 October, London : Digital Radio Development Bureau

Fesneau, E (2004) 'Elements pour une histoire public des postes a transistors en France' in Le Temps des médias, $\mathrm{n}^{\circ} 3$, autumn

JICRAR (1982) Survey of radio audiences, London : Joint Industry Committee for Radio Advertising Research

RAJAR (1997, 1999, 2006) Quarterly Summary, London : Radio Joint Audience Research Ltd, various dates

Radio Advertising Bureau (2002) Radio Days 3, London : Radio Advertising Bureau Starkey, G (2003) 'Are Radio Audiences Choosing to Reject Greater Choice?' in Ralph, $\mathrm{S}$ and Manchester, H (eds) Diversity or Anarchy?, Luton : University of Luton Press

Starkey, G (2007a) Balance and Bias : Representation, Regulation and Democracy, London : Palgrave

Starkey, G (2007b) 'Mais, est-ce encore de la radio? Programmation et transmission en mutation en temps de crise', in Wuilleme, B, La radio au tournant des siècles, Lyon : Université de Lyon

Starkey, G (2007c) 'La democratización de las medias por la proliferación a través de nuevas tecnologías, cambios en la regulación y emisoras comunitarias.' in Peñafiel, C (Ed.) Escúchame y mírame : jornadas internacionales de radio y televisión, Bilbao : Universidad del País Vasco 
